\section{Crystallography at the Swiss Federal College of Technology: Prof. J. D. Dunitz}

DR. J. D. DunItz, who has been appointed to a chair of crystallography at the Swiss Federal College of Technology, Zurich, has had a distinguished career in the field of crystal and molecular structure studies. After graduating with first-class honours in inorganic and physical chemistry at Glasgow in 1944, he joined the research team of Prof. Monteath Robertson and carried out some very accurate structure determinations on the acetylene dicarboxylic acids. Later at Oxford, with a Carnegie Senior Scholarship, and at Pasadena, with an A. A. Noyes Fellowship, he extended his work to more complex organic compounds including certain important antibiotics. While holding later appointments at the National Institutes of Health, Bethesda, and at the Royal Institution in London, he has continued to make contributions to the field of complox natural products and proteins. Dr. Dunitz's interests, however, are not confined to these problems of complex structures, and he has made several important contributions to the structural chemistry of simple inorganic molecules, and in collaboration with Dr. Orgel he has written a number of important theoretical papers. These deal with the effect of chain-length on symmetry of conjugated molecules, with the stability and structure of the molecular sandwich compounds (dicyclopentadienyl iron) and other topics. In his new and important post at Zurich Dr. Dunitz will have ample opportunity to enlarge and extend his many interests in modern structural chemistry and erystallography.

\section{American Institute of Physics : Compton Gold Medal}

ON behalf of the American Institute of Physics, H.R.H. Prince Philip conferred the first Compton Gold Medal of the Institute on Dr. G. B. Pegram, vice-president emeritus of Columbia University, for distinguished service to physics. The ceremony, which occurred in conjunction with the dedication of the new building of the American Institute of Physics at 335 East 45th Street, New York (see Nature, 179, 1167 ; 1957), was held before a group of distinguished scientists, educators and administrators in the Karl Taylor Compton Memorial Room of the new Institute on October 21. Dr. Pegram was a founder member of the American. Institute of Physics in 1931, together with the late Dr. K. T. Compton and others. He served as its first secretary for fourteen years and was treasurer for eighteen years until he retired last year. Dr. Pegram also was an officer of the American Physical Society for thirty-eight years, serving as president and treasurer. He made the first contact with the United States Government in March 1939 which resulted in the Manhattan Project, after J. R. Dunning and the late Enrico Fermi had demonstrated the release of energy by uranium fission at Columbia University.

\section{Dr. S. Fred Singer}

Dr. S. Fred Singer, associate professor in the Department of Physics, University of Maryland, is to receive a United States Junior Chamber of Commerce award as one of the ten outstanding young men of the year 1957 whose achievements have been of importance in their professions and also to the general welfare of the United States. Dr. Singer has contributed to the study of rocketry and astrophysics as the leader in design and development of three small, inexpensive rockets for upper-atmosphere research. These are the 'Rockaire', the first highaltitude research rocket launched from aircraft ; the 'Terrapin', the smallest high-altitude rocket launched from the ground; and the forthcoming 'Oriole', a ground-or ship-launched rocket which will be even less expensive and smaller. Dr. Singer has completed the design and construction of instruments for the detection of cosmic rays, to be installed in rockets to be fired in the current 'Far Side Project'.

\section{President of the Royal Australian Chemical Institute: Dr. I. W. Wark}

DR. I. W. WARK, chief of the Division of Industrial Chemistry of the Commonwealth Scientific and Industrial Research Organization, has been elected general president of tho Royal Australian Chemical Institute for 1957-58. Dr. Wark has been chief of the Division of Industrial Chemistry since its forma. tion in 1940. Under his guidance this laboratory has grown until it now has a research staff of one hundred. Among its achievements are the process using cetyl alcohol for controlling evaporation from dams and reservoirs and a method for separating hafnium from zirconium which is of significance for atomic powered submarines. Dr. Wark's own personal research was concerned with the theory of the flotation process for separating minerals from ores. His pioneering work as a physical chemist in this field gained for him a wide reputation and his book "Principles of Flotation", first published in 1938 , became recognized as a classic on the subject. He graduated at the University of Melbourne and continued his postgraduate studies at the Universities of London and California. Dr. Wark is a Fellow of the Australian Academy of Science. For many years he has taken a prominent part in the affairs of the Royal Australian Chemical Institute and has done much to gain a wider appreciation of the importance of chemistry and of science generally.

\section{A Regional. Museum Service}

ABout twenty-five years ago the museums and art galleries of Great Britain were grouped together on a regional basis for friendly advice and help. It was a type of unofficial co-operation and each member of a group or federation was completely autonomous but could rely on fellow-members for help if desired. The Museums Association now considers that this service should be placed on a more regularized basis and proposes as an experiment to endeavour to set up a regional museum service in the south-west of England. It is considered that such a service would be helpful in the identification of material, the conservation of objects, and the organization of work with the schools. As a first step towards the initiation of such a service a meeting of local authorities and other interested bodies was held at Taunton on October 15 under the chairmanship of Sir Mortimer Wheeler. The meeting was enthusiastic concerning the value and worthwhileness of such a scheme and the only doubts raised were those involving finance. After careful consideration of the factors involved, it was decided to form a committee of inquiry consisting of four representatives of the county councils, four from the municipalities, four from the South-Western Group of Museums and Art Galleries, two from the Museums Association and one from the universities within the area of the counties of Bristol, Cornwall, Devon, 